pidgin English, " $M y$ tink that peecee man dio of beri-beri." In a flash I knew he was right, though, needless to say, I rebuked bim for his freedom with portentous gravity.

My medical education had been no better and no worse than that of other young medical men; but at that moment and on many other occasions I had every reason to regret it had not been better. The present movement in favour of special instruction in tropical medicine is one with which every medical officer who has served abroad will be in hearty sympathy. Instances of mistaken diagnosis such as the above are innumerable, and it appears to me to be the duty of the leaders of the profession to take steps to remedy a crying need.-I am, Sirs, yours faithfully,

$$
\begin{aligned}
& \text { Mariborough Mansions, S.W., } \quad \text { M. T. YARR, } \\
& \text { Nov. 2nd, 1897. }
\end{aligned}
$$

\section{"PROPOSED AMENDMENTS OF THE NOTIFICATION ACT."}

\section{To the Editors of THE LANOET.}

SIRS,-I notice in THM LANCET of Oct. 30th a criticism of a report I made to the Crewe Town Council on the above subject, and I beg to thank you for it and to acknowledge its fairness. I shall be glad, however, if you will allow me a few words of self.justitication. The first point you raise is one which was modified in the memorial to the Local Government Board which was passed under the seal of this council on the $28 \mathrm{th}$ ult. The recommendation now reads :-

"That as one notification brings the infected premises to the notice of the medical officer of health subsequent cases of the same disease accurring in members of the same family resident in the same house, within twenty-eight days of the date of such first notification and notiffed by the same practitioner should be paid for at a reduced fee of notited by the same practitioner shonid be paid for at a reduced fee of 18. for each case, the fee for any disease included in the Schedule of by any other practitioner to be paid for at the usual rate of $2 s .6 \mathrm{~d}$. per case."

I am prepared after careful consideration to stand by that as a reasonable and fair arrangement. Naturally, medical practitioners would rebel at this, but as a medical officer of health I have (to say the least) a bias towards the care of the public purse.

With reference to the second point (payment of $1 s$. as fee for notification of the milder infections diseases) I am afraid your critic takes a wrong view of the matter. The local authority do not pay the medical practitioner for his diagnosis-he diagnoses the case for his own ends and for the satisfaction of his patient. The local authority ask bim when he has made his diagnosis for these ends to acquaint them, in certain specified cases, on a form which they provide for the purpose. Medical officers of bealth everywhere, I venture to think, know what their reply rould be if they endeavoured to persuade their local anthorities to include as notifiable diseases, for which a fee of $2 s, 6 d$. per case would have to be paid, chicken-pox, measles, whooping-cough, \&c. There would in 99 per cent. of the cases be absolutely no hope of support, for the local anthorities would say, "Is the information as to the existence of these milder diseases of such great value to us at present as that of small-pox, scarlet fever, or typhoid fever? $\mathrm{N}_{0}$; then we think we ought not to pay so much for the information." But if we ask them to include the milder diseases at a lower fee, then there is much more hope of their giring in and the medical practitioners would benefit correspondingly.

In short, Sirs, to be perfectly plain, the medical practitioner's views of the matter are necessarily selfish and they are obriously, I think, the views of your critic; the views of the medical officer of health are for the greater part unselfish and are necessarily in conflict with those of private practitioners. There are cases (and it appears to me that this is one) in which the medical officer of bealth is sorely divided between his duty to his local authority and that to his medical brethren. I have endeavoured to be fair to both, and I feel confident that my brethren who are public officials will see pretty much as I do. In case you care to see it I enclose a copy of the actual memorial which has been sent to the Local Government Board by my town council, and when I tell you that this town council were strongly opposed to the Notification Act for many years and only adopted it on the repeated strong representations of my predecessor, Dr. Herbert Jones, in October, 1896 (exactly one year ago), I think you will admit that Crewe are by their recent action upholding their municipal motto, "Never Behind." I thank you, Sirs, for your anticipated insertion of this letter, and I repeat my thank for your straightforward criticism.

I am, Sirs, yours faithfully,

MerediTH YounG, M.D. Edin., D.P.H. Vict.s Medical Officer of Health.

Health Department, Municipal Offices, Earlestreet, Crewe, Nov. 2nd, 1897.

\section{A DISCLAIMER.}

To the Editors of THE LANOWT.

SrRs,-Will you kindly allow me to say through your journal that I am no relation of, or in any way connected with, the man convicted of fraud at the Central Criminal Court on Oct. $29 \mathrm{th}, 1897$, under the name of Theophilus Turner and described as passing as a surgeon? Theophilus was not his name at all-only one of his many aliases. I beg to say that I am the only Theophilus Bryett Turner in the Medical Register, and was very much surprised that I was not put into the witness-box to state this fact and so protect myself. Apologising for tronbling you, I am, Sirs, yours faithfully, T. B. TuRNER

“Coniston," 7, Warminster-road, South Norwood-park, Nov. 3rd, 1897.

** We sympathise with Mr. Turner, and beg to add a' protest against the loose way in which every scamp who dabbles in drugs or bone-setting to the detriment of the public health is always described on reaching the dock as a. " doctor, a "surgeon," or a " medical man."-ED. L.

\section{THE PATHOLOGY OF THE PERNICIOUS MALARIAL FEVERS.}

To the Wditors of THE LANOHT.

SIRs,-In your report of my remarks in the discussion on Dr. Thin's paper at the meeting of the Royal Medical and Chirurgical Society on Tuesday last, I am represented as having spoken of typho-malarial fever, whereas I spoke of the æstivo-autumnal, or irregular, fever of malaria. Dr. Thin's subject was the Pathology of the Pernicious Malarial Fevers, and typho-malarial fever is not one of them.

Nov. 2nd, 1897. I am, Sirs, yours truly,

\section{THE LONDON FREE HORSE AMBULANCE SERVICE. \\ To the Editors of THE IANOET.}

SIRs,-Will you kindly aid me in making it known to the profession that in the north, south, and south-west districts of Liondon horse ambulances are stationed and are always available without charge for the vehicle for any case of accident or of disease which is not contagious. The costs which in the absence of any fund have to be paid by the applicant, come in all to $7 s$., with cab rate of increase if for over two miles. These are for the horse, 5 s., cleaning 1 s., driver $1 s$. As private ambulance carriages cost a minimum of $25 s$. to $42 s$., this provision by the London Horse Ambulance Society will be seen to be of great help to such as are in neec of it.

That this need exists has been cariously but fully demonstrated in the history of the organisation. From the time of its completion, and during my absence from England, not a single public announcement, I am told, has been made of its existence yet from an official report from each station kindly supplied to me by Sir Edward Bradford, Chief Commissioner of the Metropolitan Police, it will be seen that whereas in 1884 when the society was organised under the auspices of H.K.H. the Duke of Cambridge the carriages were used by only fourteen persons, in 1895 this number had steadily increased to one hundred and nineteen for that year and in all to nearly five hundred. On a recent inspection in detail I found each carriage to be exquisitely clean, in perfect order and in readiness to start at a moment's notice. At all the stations I found the interest displayed by the police oflicers in the successful use of these vehicles amounted to enthusiasm, fairly reflecting the admirable spirit of the Chief Commissioner to whose kindly coöperation the good that has been accomplished is so largely due.

The way to obtain one of these carriages is very easy. Anywhere within the metropolitan area any person desiring one has simply to state his wishes at the nearest police 